\title{
Isolation and Partial Characterisation of Bacteriocin Produced By Lactobacillus Fermentum
}

\author{
K. Vanmathi Selvi*, R.Kanthamani ${ }^{1}$ \\ * PG \& Reaserch Department of Microbiology, Sri Akilandeswari Women's College, Vandavasi, T.V.Malai, \\ Tamil Nadu, India. \\ '. PG \& Reaserch Department of Microbiology, Sri Akilandeswari Women's College, Vandavasi, T.V.Malai, \\ Tamil Nadu, India.
}

\begin{abstract}
The present study was confined to the velar estuary in Cuddalore District, Tamil Nadu.Water samples were collected to isolate the bacteria. The collected samples were plated (MRS agar), incubated and the Bacterial colonies were identified. Effect of different ecological parameters such as $\mathrm{pH}(6-11)$, temperature $\left(30-60^{\circ} \mathrm{C}\right)$, salinity (0.5-3\%), substrates (carbon \&nitrogen source) on the growth of bacteria was also determined. Maximum bacterial growth was observed in $\mathrm{pH} 9,35^{\circ} \mathrm{C}$ temperature, $2 \%$ salinity, $1 \%$ glucose as carbon source and $0.5 \%$ sodium nitrate as nitrogen source after $24 \mathrm{hrs}$ of growth in liquid medium. The potential strain was selected by the antimicrobial well assay method. Lactobacillus fermentum (Bacteriocin) contains inhibitory activity against histamine producers 10 strains). Antimicrobial activity was tested against 10 human pathogens. The protein bands were observed using SDS-PAGE and their molecular weight ranging from 78KDa.
\end{abstract}

Keywords: Growth characteristics - Effect of physical and chemical parameters, SDS-PAGE, Lactobacillus fermentum (Bacteriocin)

\section{Introduction}

Bacteriocins are polypeptides, with bactericidal or bacteriostatic activity, against those bacteria which are closely related to the producer strain (Klaenhammer, 1998 and Tagg et al., 1976). Bacteriocins are highly specific antibacterial proteins produced by strains of bacteria active mainly against some other strains of same or related species (Gaur et al., 2004).Bacteriocins were first discovered by A.Gratia in 1925. He was involved in the process of searching for ways to kill bacteria, which also resulted in the development of antibiotics and the discovery of bacteriophage, all within a span of a few years. He called his discovery a colicin because it killed E.coli. The bacteriocins produced by gram positive bacteria, in particular, the lactic acid bacteria display fairly broad inhibitory spectra with food preservative (Galvez et al., 2008) and therapeutic (Jack et al., 1995) potentials. Bacterial strains with antimicrobial activity play an important role in the food industry, agriculture and pharmaceutical industry. Many bacterial species inhabit the ecological niches with a limited amount of nutrients. Because of this, many bacterial species produce a variety of antimicrobial substances, such as lactic acid, acetic acid, diacetyl, hydrogen peroxide and the other substances including enzymes, defective phages and lytic agents with potential importance for food fermentation and biopreservation (Lindgren and dobrogosz, 1990).

Bacteriocin production seems to be aimed to compete against other bacteria which are present in the same ecological niche (Barefoot et al., 1993 and Dykes, 1995 and Riley,1998). Different bacteriocin exhibits different profile on food spoilage and pathogenic microorganisms. Therefore, they could be natural replacements for synthetic food preservatives. Bacteriocin production has been reported to be affected by several factors including carbon and nitrogen sources and fermentation conditions, such as $\mathrm{pH}$, temperature and agitation (Kim et al., 2006). Bacteriocinogenic bacterial strains appear to be an excellent candidate for a friendly alternative since bacteriocin would be used as an antibiotic substitute (Joerger et al.,2003), whereas bacteria would be a potential probiotic (Gillor et al., 2008). The use of bacteriocins or the microorganisms that produce them is attractive to the food industry in the face of increasing consumer demand for natural products and the growing concern about food borne diseases (Joshi et al., 2006).

Till the end of 1950, a very few of the food items were processed and packaged, processed and packaged foods were luxury item in colonial times but after 1960, these food items were in great demand globally due to growing urbanization, breakdown of large families in to nuclear families and increase in the number of working women. Chemical preservatives and other traditional barriers have been used in the food products to inhibit microbial growth which led to serious health diasasters, thus challenging the food scientist for providing safer and healthier food. Food preservation has become a major issue because food borne pathogens can cause havoc in preserved /fresh food items at high temperature, room temperature and even at low temperature (Sharma et al., 2006). However consumer demand for faster, healthier and ready -to-eat 
products have strongly demanded the use of more natural preservatives instead of chemical preservative. Microbiologists around the world became interested in bacteriocin production the requirement of food preservation.

The following requirements should be fulfilled by any biopreservative to be used commercially (Holo et al., 2002; Kim and Bhowmik 1990 and Mauriello et al., 1999).

1. The biopreservative to be used should not be toxic.

2. It should be accepted by recognized authorities.

3. It should be economical to the industries using it.

4. The product in which the biopreservative is being used should not be affected by it, i.e. biopreservative should not show any deleterious effect toward the organoleptic properties of that product.

5 . When used at relatively low concentrations it should show effectiveness.

6. The biopreservative should be sufficiently stable in storage.

7. It should not have any medicinal use.

Bacteriocins fulfil all the above requirements and hence are gaining popularity in the food industry day-by-day. Bacteriocins have been grouped into four main distinct classes (Klaenhammer, 1993).

\begin{tabular}{|l|l|}
\hline Class I & $\begin{array}{l}\text { Lantibiotics characterized by the presence of unusual thioether amino acid which are generated through } \\
\text { translational modification. }\end{array}$ \\
\hline Class II & Bacteriocin represent small(<10KD) heat stable, membrane active peptides. \\
\hline Class II A & $\begin{array}{l}\text { Subclass II A represented by Listeria active peptides which contain the N terminally located consensus } \\
\text { sequence YGNGCXV where X is any amino acid. }\end{array}$ \\
\hline Class II B & Representing portion complexes that require two different peptides for activity. \\
\hline $\begin{array}{l}\text { Subclass II } \\
\text { C }\end{array}$ & $\begin{array}{l}\text { Peptide whose exterrnalization into the growth medium of the producing bacterium is dependent on the } \\
\text { general secretory pathway. }\end{array}$ \\
\hline Class III & Bacteriocins belonging to class III consist of large $>30 K D)$ heat labile protein. \\
\hline Class IV & $\begin{array}{l}\text { Represent complex bacteriocin that contain essential lipid, carbohydrate moieties in addition to a protein } \\
\text { compared. }\end{array}$ \\
\hline
\end{tabular}

Kollath was the first to suggest, in 1953, the term "probiotics" to designate organic or inorganic substances that are essential to a healthy development of life (Kollath, 1953). Probiotics are live microorganisms that, when consumed in an adequate amount as part of the food, confer the health benefit on the host (FAO/WHO, 2001). An experimental focus on bacteriocin production by probiotic LAB strains has indicated that this potential might play a considerable role during invivo interactions occurring in the human gastrointestinal tract, for instance towards H. pylori (De vuyst et al., 2004; Avonts and De vuyst 2001 and Kim et al., 2003).

The properties of L.acidophilus have been investigated in order to establish its specific role in the complex microbial equilibrium, both of man and higher animals. Among the Lactobacillus species, L. acidophilus strains have been extensively utilized as probiotic cultures in dairy and pharmaceutical products and numerous report have proved its ability to produce bacteriocin (De souza et al., 2005).

\section{Collection of samples}

\section{Materials And Methods}

Water samples were collected from Vellar estuary and they were serially diluted. $0.1 \mathrm{ml}$ from $10^{-4}, 10^{-5}$, $10^{-6}$ dilutions were spread plated over the surface of the MRS agar plates. The plates were incubated at $37^{\circ} \mathrm{C}$ for three days. The colonies were observed.

\section{Identification of the potential strain}

The strains were identified according to the method described by Buchanan et al., 1974.The tests are given in Table1.

\section{Antimicrobial activity against human pathogens}

Nutrient broth was prepared and sterilized. Ten different human pathogens such as S.aureus, Salmonella typhi, S.paratyphi, K.oxytoca, P.aeruginosa, E.coli, P.mirabilis, L. bulgaricus, V.cholerae and K.pneumoniae were inoculated separately and kept for incubation. Nutrient plates were swabbed with $0.1 \mathrm{ml}$ of different human pathogens. After swabbing, wells were punctured and cell free extracts of different strains of Lactobacillus was poured in to individual well and kept for incubation at $37^{\circ} \mathrm{C}$. The plates were observed for a clear zone of inhibition and measured after $24 \mathrm{~h}$. The potential Lactobacillus strain was selected based on the diameter of the zone of inhibition given in Table2. 


\section{Antimicrobial activity against Histamine producers}

Fish samples were collected from Chidambaram fish market. Samples were serially diluted and appropriate dilutions were plated on the mineral medium incorporated with filter sterilized histidine of $1 \mathrm{~g} / 100$ $\mathrm{ml}$ and kept for at room temperature $28 \pm$ for $24 \mathrm{~h} .250 \mathrm{ml}$ of nutrient agar was prepared, autoclaved and poured on the plates. It was swabbed with histamine producer colonies which was already available in the research laboratory. The wells were punctured on the plates and $0.1 \mathrm{ml}$ of Lactobacillus culture filtrate was added and kept for incubation at $37^{0} \mathrm{c}$ for three days.

\section{Optimization for growth}

The factors like $\mathrm{pH}$, temperature, salinity and substrate concentration which were expected to influence the production of bacteriocin by the selected strain were optimized by selecting one parameter at a time.

\section{Effect of $\mathrm{pH}$ on growth}

Different $\mathrm{pH}$ (i.e.) $6,7,8,9,10,11$ were maintained in the medium. Growth and activity were assessed for every $6 \mathrm{hrs}$.

\section{Effect of Salinity on growth}

Different salinity $0.5 \%, 1 \%, 1.5 \%, 2 \% 2.5 \%$ and $3.0 \%$ were maintained in the medium. Growth and activity were assessed for every $6 \mathrm{hrs}$.

\section{Effect of Substrates on growth}

The carbon source, glucose $(1.0 \%)$ and nitrogen source, peptone $(0.5 \%)$ were maintained in the medium. Growth and activity were assessed for every $6 \mathrm{hrs}$.

\section{Mass scale culture for bacteriocin production in shake flask}

The optimized conditions, temperature- $35^{\circ} \mathrm{C}$, salinity- $2 \%$, Glucose- $2 \%$, peptone- $2 \%$ were maintained in the medium $(250 \mathrm{ml})$. Four such flasks were kept for incubation at $35^{\circ} \mathrm{C}$ in a shaker for $24 \mathrm{hrs}$.

\section{Ammonium sulphate precipitation and dialysis}

The shake flasks kept for mass scale production were taken after $24 \mathrm{hrs}$ and centrifuged at 15,000 rpm for 10min. To the supernatant, the amount of ammonium sulphate required to give $80 \%$ saturation was added slowly with stirring. Dialysis was followed in a tubular cellulose membrane against $2 \mathrm{~L}$ distilled water for $24 \mathrm{hrs}$ at $4^{\circ} \mathrm{C}$.

\section{Lyophylization}

The partially purified bacteriocin was lyophilized in a Vertis lyophilizer and kept for further analysis.

SDS-PAGE (Protein profile)

Protein Separation- SDS-PAGE-(Laemmli, 1973): The proteins were separated by SDS-PAGE electrophoresis and size of polypeptide chains of given protein can be determined by comparing its electrophoretic mobility in SDS-PAGE gel with mobility marker proteins of known molecular weight.

\section{Result}

Lactic acid bacteria were isolated from water samples, Vellar estuary using MRS agar. The colonies were creamy white, transparent and smooth round in shape. The selected strain was identified as Lactobacillus fermentum based on its, morphological, physiological and biochemical characteristics. The strain was gram positive, non motile, non spore forming and rod shaped. It showed positive reaction in oxidase, fermentation in fructose, glucose and mannitol. It was catalase negative and negative in MR-VP test and nitrate reduction. It did not produce pigment (Table: 1 ).

Table: 1 Biochemical identification of Lactobacillus fermentum

\begin{tabular}{|l|l|}
\hline \multicolumn{1}{|c|}{ Test } & \\
\hline Gram's staining Result \\
\hline Motility & + Rod \\
\hline Morphological characteristics & Non-motile \\
\hline Spore & Small, circular and smooth \\
\hline Pigment & Non-spore forming \\
\hline Bile esculin & - \\
\hline Bile solubility & - \\
\hline Indole & Insoluble \\
\hline Methyl red & - \\
\hline Voges Proskaur & + \\
\hline Citrate utilization & - \\
\hline Nitrate reduction & + \\
\hline Growth on acetate & - \\
\hline Ribose fermentation & + \\
\hline Growth at $50^{\circ} \mathrm{C}$ & + \\
\hline Growth at $45^{\circ} \mathrm{C}$ & - \\
\hline pH 3 & + \\
\hline Production of $\mathrm{H}_{2} \mathrm{~S}$ & - \\
\hline Production of $\mathrm{H}_{2} \mathrm{O}_{2}$ & - \\
\hline
\end{tabular}


Antimicrobial activity was tested against ten major human pathogens such as Staphylococcus aureus, Salmonella typhi, S.paratyphi, K.oxytoca, P.aeruginosa, E.coli, P.mirabilis, L. bulgaricus, V.cholerae and K.pneumoniae. Surprisingly all of them were found to be sensitive to Lactobacillus fermentum. Lactobacillus fermentum showed inhibitory activity to the pathogens in the order of P.aeruginosa, Staphylococcus aureus, K.oxytoca, L. bulgaricus, Salmonella typhi, E.coli, Vibrio cholerae, Salmonella paratyphi, P.mirabilis and K.pneumoniae. (Table: 2)

Table 2: Antimicrobial activity of Lactobacillus fermentum

\begin{tabular}{|l|c|}
\hline \multicolumn{1}{|c|}{ PATHOGENS TESTED } & ZONE OF INHIBITION (mm) \\
\hline Staphylococcus aureus & 10 \\
\hline Salmonella typhii & 8 \\
\hline Salmonella paratyphi & 7 \\
\hline Klebsiella oxytoca & 8 \\
\hline Pseudomonas aeroginosa & 12 \\
\hline Escherichia coli & 8 \\
\hline Proteus mirabilis & 7 \\
\hline Lactobacillus bulgaricus & 8 \\
\hline Vibrio cholera & 8 \\
\hline Klebsiella pneumonia & 7 \\
\hline
\end{tabular}

In the present study histamine producers were isolated from fish samples obtained from the local market and checked with Lactobacillus fermentum strain for the inhibitory activity (Fig:3). 10 different histamine producing strains were inhibited by Lactobacillus fermentum (Table-3).

Table:3 Antimicrobial activity of L. fermentum culture filtrate against Histamine producers

\begin{tabular}{|l|l|}
\hline Histamine Producers & Zone of inhibition (mm) \\
\hline H1 & 9 \\
\hline H2 & 10 \\
\hline H3 & 5 \\
\hline H4 & 7 \\
\hline H5 & 11 \\
\hline H6 & - \\
\hline H7 & 3 \\
\hline H9 & 13 \\
\hline H10 & 5 \\
\hline
\end{tabular}

The optimal growth conditions for bacteriocin production were found to be at $\mathrm{pH} 9,35^{\circ} \mathrm{C}, 2 \%$ salinity, glucose$1.0 \%$ as carbon source, $0.5 \%$ sodium nitrate as nitrogen source with $24 \mathrm{hrs}$ incubation.

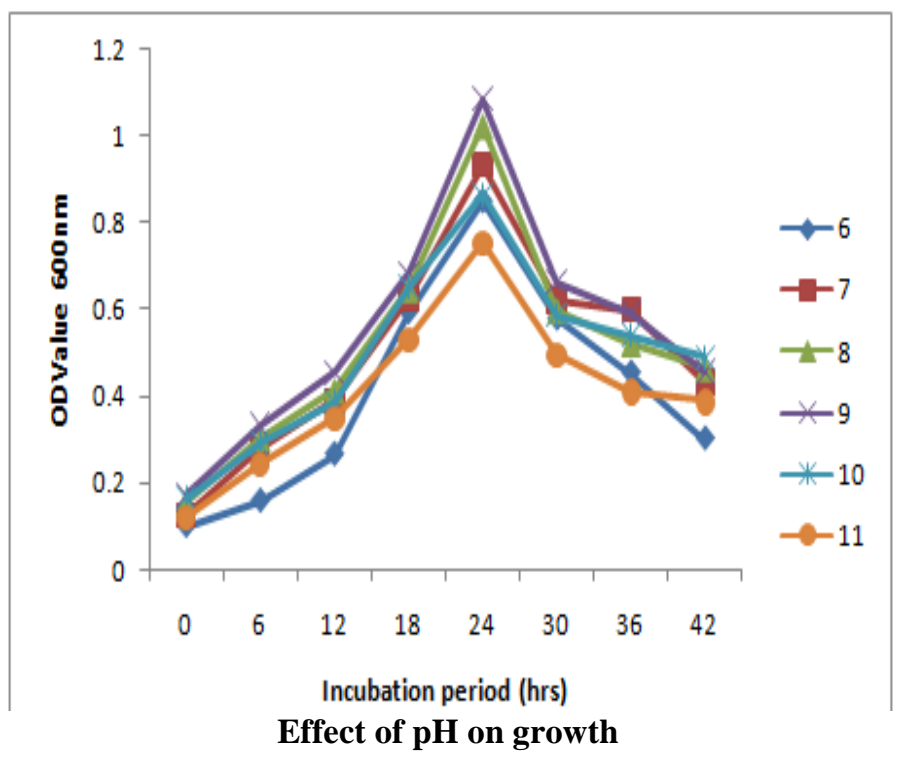




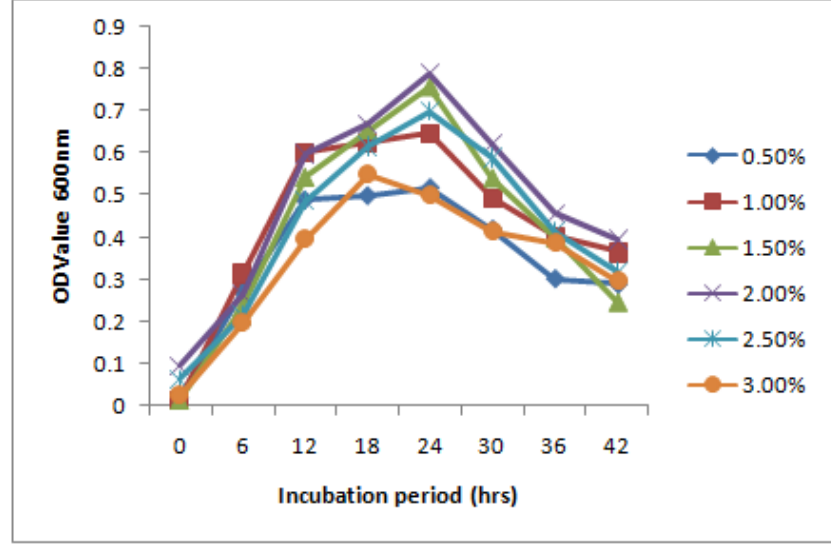

Effect of Substrates on growth

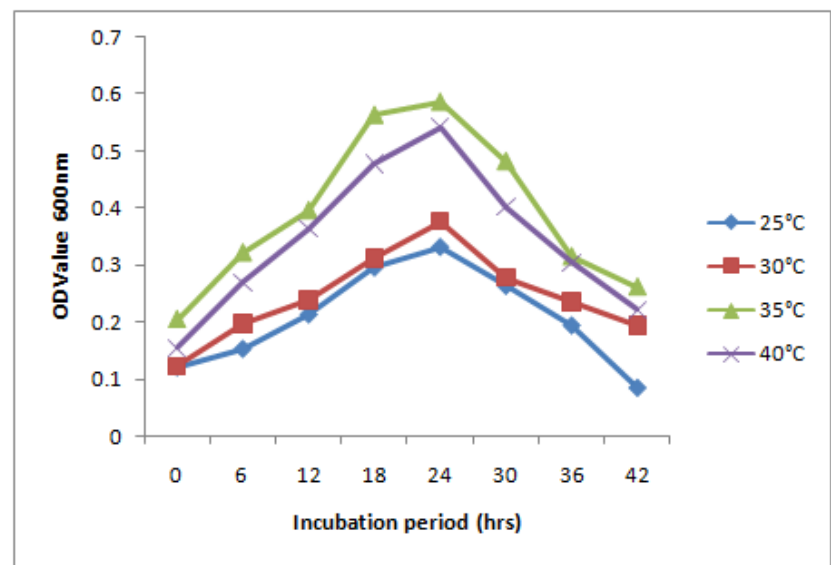

Effect of Temperature on growth



Effect of Carbon source on growth

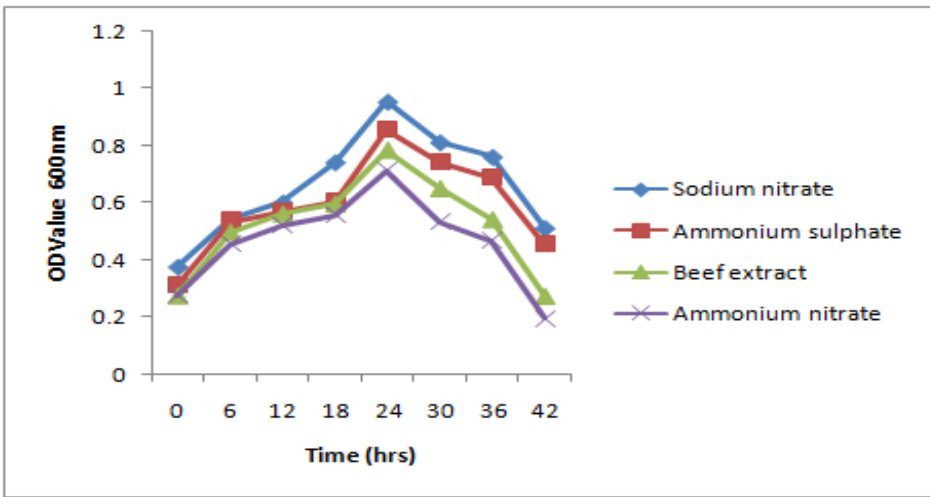

Effect of Nitrogen sources on growth 


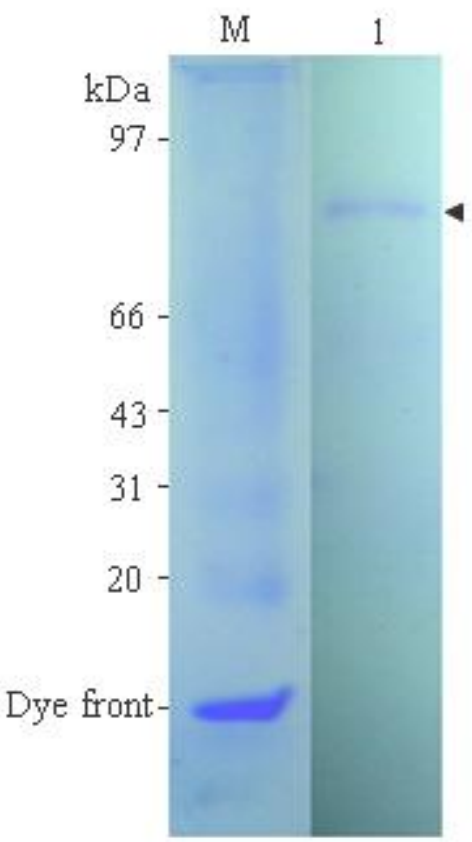

Lane 1: Sample Protein

Lane M: Standard Protein Molecular Weight Marker

\section{Protein analysis of Bacteriocin}

\section{Summary And Conclusions}

Some Lactobacillus spp. are used industrially for the production of Yoghurt, Cheese, sauerkraut, pickles, beer, wine, cider, kimichi, chocholate and other fermented foods, as well as animal foods, such as silage. Some Lactobacillus spp. and other lactic acid bacteria may possess potential therapeutic properties including anti-inflammatory and anti-cancer activites, as well as other features of interest. Research studies have demonstrated the protective effects of some strains of these bacteria for anti-tumor and anti-cancer effects. Reports also indicated that some cultures administrated to animals inhibited liver, colon, bladder and mammary tumors, highlighting potential systemic effects of probiotics with anti-neoplastic activities.

The present study showed that the bacteriocin of Lactobacillus fermentum is a protein with antimicrobial effects on some clinically important food borne pathogens and histamine producers. This reveals the potential application of bacteriocin produced by L.fermentum as a protective culture for the improvement of the microbial safety of fermented foods and reduction in food contamination which causes illness to human beings. The present study thus confiemed the possibility of using the strain L. fermentum as a biopreservative and a probiotic.

In the present studies, Lactobacillus fermentum also contains the high protein content and antimicrobial activity. This strain was isolated from the marine sample and they were identified and cultivated using MRS agar. The potential strain was selected by the antimicrobial well assay method. Lactobacillus fermentum contains inhibitory activity against histamine producers also. The protein bands were observed using SDSPAGE and their molecular weight ranging from 78KDa. The bacteriocin produced were rechecked.

\section{References}

[1] Abee, T., L.Krockel and C.Hill, 1995. Bacteriocins:modes of action and potentials in food preservation and control of food poisoning. Int. J. Food Microbiol., 28:169-185.

[2] Andersen, E.L., D.B. Diep, I.F. Nes, V.G.H. Eijsink, J. Nissen-Meyer, 1998. Antagonestic activity of Lactobacillus plantarum CII: two new two-peptide bacteriocins, plantaricins EF and JK, and the induction factor plantaricin A. Appl. Environ. Microbiol., 64:2269-2272.

[3] Corsetti, A, M. Gobbetti, E. Samcchi, 1996. Antibacterial activity of sourdogh Lactic acid bacteria: isolation of a bacteriocin like inhibitory substance from Lactobacillus sanfrancico C57. Food Microbiol., 13:447-456.

[4] Diep, D.B. and I.F. Ner, 2002. Ribosomally synthesized antibacterial peptides in gram positive bacteria. Curr. Drug Targ., 3:107122.

[5] Ennahar, S., D. Aoude-werner, O. Sorokine, A. Van Dorsselaer, F. Bringel, J.C. Hubest, and C. Hasselman, 1996. Production of pediocin ACH by Lactobacillus plantarum WHE 92 isolated from cheese. Appl. . Envion. Microbiol., 62:4381-4387.

[6] Jones, R.J., H.M. Hassein, M. Zagovac, G. Brightwell and J. R. Tagg, 2008. Isolation of lactic acid bacteria with inhibitory activity against pathogens and spoilage organisms associated with fresh meat. Food Microbiol., 25:228-234.

[7] Kitazawa, H., T. Ino, Y. Kawai, T. Itoh and T.Saito, 2002. A novel immunostimulating aspect of Lactrobacillus gasseri: induction of Gasserokine as chemoattractants for macrophages. Int. J. Food Microbiol., 77:29-38. 
[8] Lee, N.K. and H. D. Paik, 2001. Partial characterization of lacticin NK24, a newly identified baceriocin of Lactococcus lactis NK24 isolated from Jeot-gal. Food Microbiol., 18, 17-24.

[9] Maldonado. A., J.L.R. Barba, B. Floriano and R.J. Diaz, 2002. The locus responsible for production of plantaricins, a class bacteriocin produced by Lactobacillus plantarum LPCO10, is widely distributed among wild-type Lactobacillus plantarum strains isolated from olive fermentations. Intern. J. Food microbial., 77 :117-124.

[10] Suma, K., M.C. Misra and M.C. Varadaraj, 1998. Plantaricin LP84, a broat spectrum heat-stable bacteriocin of Lactobacillus plantarum NCIN 2084 produced in a simple glucose broth medium. Intern. J. Food microbiol., 40:17-25.

IOSR Journal of Pharmacy and Biological Sciences (IOSR-JPBS) is UGC approved Journal with Sl. No. 5012, Journal no. 49063.

K. Vanmathi Selvi. "Isolation and Partial Characterisation of Bacteriocin Produced By Lactobacillus Fermentum ." IOSR Journal of Pharmacy and Biological Sciences (IOSR-JPBS) 12.4 (2017): 38-44. 